\title{
Rediscovery of the Badegoule 5 skeletal remains (Badegoule, le Lardin-Saint-Lazare, Dordogne, France)
}

Redécouverte des vestiges humains «Badedgoule 5» (Badegoule, commune du Lardin-Saint-Lazare, Dordogne, France).

Wiederentdeckung der menschlichen Skelettreste «Badegoule 5» (Badegoule, Kreis Le Lardin-Saint-Lazare, Dordogne, Frankreich).

Wilfried Rosendahl, Bruno Maureille and Erik Trinkaus

\section{OpenEdition}

\section{Journals}

Electronic version

URL: http://journals.openedition.org/paleo/1345

DOI: $10.4000 /$ paleo.1345

ISSN: 2101-0420

\section{Publisher}

SAMRA

\section{Printed version}

Date of publication: 1 December 2003

Number of pages: $273-278$

ISSN: $1145-3370$

\section{Electronic reference}

Wilfried Rosendahl, Bruno Maureille and Erik Trinkaus, « Rediscovery of the Badegoule 5 skeletal remains (Badegoule, le Lardin-Saint-Lazare, Dordogne, France) », PALEO [Online], 15 | 2003, Online since 04 August 2010, connection on 07 July 2020. URL : http://journals.openedition.org/paleo/1345 DOI : https://doi.org/10.4000/paleo.1345

This text was automatically generated on 7 July 2020 .

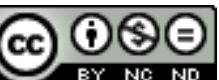

PALEO est mis à disposition selon les termes de la licence Creative Commons Attribution - Pas d'Utilisation Commerciale - Pas de Modification 4.0 International. 


\section{Rediscovery of the Badegoule 5 skeletal remains (Badegoule, le Lardin-Saint-Lazare, Dordogne, France)}

Redécouverte des vestiges humains «Badedgoule 5» (Badegoule, commune du Lardin-Saint-Lazare, Dordogne, France).

Wiederentdeckung der menschlichen Skelettreste «Badegoule 5» (Badegoule, Kreis Le Lardin-Saint-Lazare, Dordogne, Frankreich).

Wilfried Rosendahl, Bruno Maureille and Erik Trinkaus

\section{Introduction}

1 The site of Badegoule $\left(45^{\circ} 08^{\prime} \mathrm{N}, 1^{\circ} 12^{\prime} \mathrm{E}\right.$ ) is in the Lardin-Saint-Lazare commune ( $38 \mathrm{~km}$ east of Perigueux, Dordogne, France) at the base and the extremity of a limestone cliff facing south, on the left bank of a tributary of the Le Cern brook (a right tributary of the Vézère river; fig. 1). The site may have been a huge living place, covering a large surface on the slope of the present relief (at least $50 \mathrm{~m}$ long and $20 \mathrm{~m}$ deep). 
Figure 1 - Localization of the Badegoule site, Lardin-Saint-Lazare commune, Dordogne (drawing M. Seurin, UMR 5809 CNRS).

Figure 1 - Localisation du site de Badegoule, commune du Lardin-Saint-Lazare, Dordogne (dessin M. Seurin, UMR 5809 CNRS).

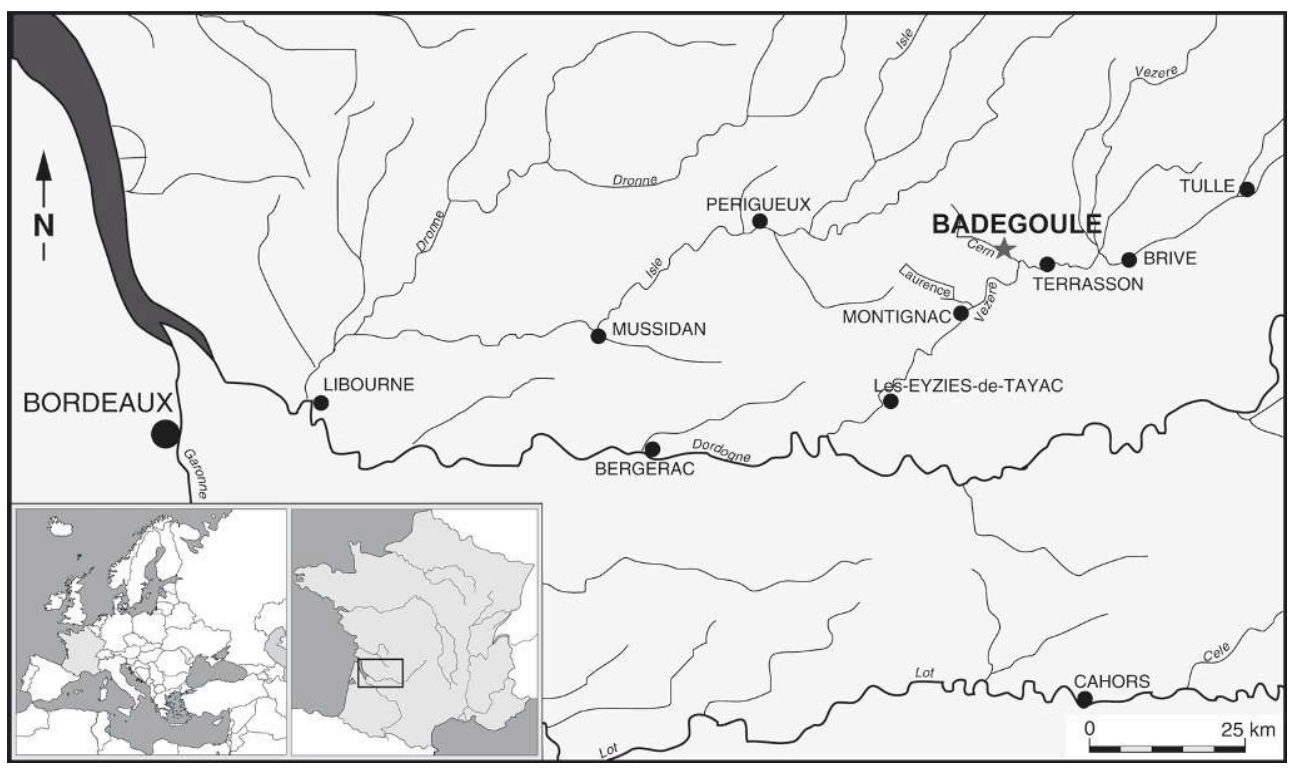

It was discovered in 1815 by $\mathrm{F}$. Jouannet and was well known as an archaeological place during the XIXth century and the beginning of the XXth century, such that many more or less conscientious excavators worked there. Between 1909/10 and 1911, O. Hauser rented the site (Hause, 1911a) but we have no precise information about his research (Hauser ibidem, p. 20). More recently, there have been excavations by A. Cheynier (1930, 1948) and by J. Couchard (1966). The latter has worked in a different locus named Badegoule Ouest. For a complete review of this historical aspect and a map of the extent of these excavations, see Cretin 2000.

Badegoule is the eponymous site of the Badegoulian lithic industry and is an important place for our knowledge about the Solutrean and early Magdalenian cultures in southwestern of France.

Because of the series of excavations made at Badegoule, the precise stratigraphy of this site is still not well known, even though the results of Peyrony (1908) and Cheynier (1939, 1948, 1949), who excavated in the same locus (Badegoule central), can be correlated. For Peyrony (1908) from the base to the top it is possible to distinguish : A = Solutrean (brown level), B = Poor (scree), C = Solutrean (red level), D = Magdalenian (dark brown conglomerate), $\mathrm{E}=$ Poor (sandy level), $\mathrm{F}=$ Magdalenian (brown level), $\mathrm{G}=$ Recent soil. For Cheynier $(1939,1948,1949)$ from the base to the top of the stratigraphy, there is : I = Solutrean, a sterile level, II = Middle Solutrean (rubble), III = Middle Solutrean (black with ashes), IV = Upper Solutrean (grey level), $\mathrm{V}=$ Final Solutrean (grey level), VI = early Proto-Magdalenian (dark-red hard brecchia), VII = early ProtoMagdalenian (clear-yellow fine, smooth, powdery brecchia). According to Taborin and Thiébault (1994), the correlation between the Peyrony and the Cheynier stratigraphies could be the following : A, C and D = IV and V; D and F = VI and VII. At Badegoule Ouest, we can note that Couchard (1966) defined at the top of his stratigraphy (level D), a white powdery breccia, smooth but resistant which is the equivalent of the level VII of Cheynier (cf. supra ; Cretin 2000). 


\section{Hominid remains from Badegoule}

5 During the excavations at the Badegoule rock-shelter (Badegoule central) between 1869 and 1940, several human cranial and postcranial remains were found. In total, eight human specimens are listed in the catalogues of fossil hominids and these remains are listed and very briefly described below.

- Badegoule 1 : temporal bone (fragmentary), adult, discovered by E. Massénat in 1869 (Massénat 1869) ;

- Badegoule 2 : cranium (very fragmentary), adult, discovered by R. Tabanou 1903 (Champagne 1905);

- Badegoule 3 : cranium (fragmentary) and a mandible, both remains belong to a juvenile (7-8 yrs), discovered by R. Tabanou 1903 (Champagne 1905). It would be better to name these pieces Badegoule $3 \mathrm{a}$ (calotte) and $3 \mathrm{~b}$ (mandible). The $3 \mathrm{~b}$ piece is in the Muséum d'Histoire Naturelle de Lyon ;

- Badegoule 4 : incisor, adult, discovered by D. Peyrony in 1907 (Peyrony 1908). It was supposed to be at the Musée national de Préhistoire in Les-Eyzies-de-Tayac (Bouvier in Oakley et al., 1971) but, at present, is not in the recorded human fossil collections of this institution ;

- Badegoule 5 : cranium (very fragmentary), juvenile, discovered by O. Hauser 1910 (Hauser 1911b).

- Badegoule 6 : P3 and P sin., adult, discovered by A Cheynier 1928-1940 (Cheynier 1949, Sonneville-Bordes 1959). These teeth should be named as Badegoule 6a (P3) and Badegoule $6 \mathrm{~b}$ (P sin.);

- Badegoule 7 : dm1 dex., discovered by A Cheynier 1928-1940 (Cheynier 1949, SonnevilleBordes 1959) ;

- Badegoule 8 : three molars, adult, discovered by L. Peyrille 1933 (Sonneville-Bordes 1959). The three molars should be named Badegoule $8 \mathrm{a}-\mathrm{c}$.

The Badegoule 6a, 6b, 7 and 8 (only two of the three molars) may be in the Institut de Paléontologie Humaine, Paris (Bouvier in Oakley et al., 1971). For all of the other listed remains, the whereabouts are unknown. Note also that the human remains from the Badegoule-Ouest site (Badegoule-Ouest 1 to 13, Gambier and Houet 1993), excavated by J. Couchard and L. Peyrille (Couchard 1966) are not considered here.

\section{The rediscovery of Badegoule 5}

7 In addition to his final excavations at the lower rock-shelter of the Le Moustier site in 1910, Otto Hauser ${ }^{1}$ worked at the Badegoule rock-shelter. In a short article about this excavation, Hauser reported that he found fragments of a skullcap from a juvenile, embedded in calc-tufa (Hauser 1911b). These are the Badegoule 5 hominid remains. In the same article, Hauser also reported the discovery of a human calotte fragment from the lower Abri of Le Moustier. Given the numbering of the other human remains known from Le Moustier, this find should be named «Le Moustier 3» (Rosendahl, in press). Note that Hauser mentions, in a popular book, that he has also discovered, in 1908, an isolated tooth at Le Moustier (Hauser 1928 : 302).

Unfortunately, there is no further description of either specimen in the article of Hauser (1911b, 1928). In Obermaier (1911/1912 : 436), Hauser (1925 : 206), Vallois and 
Movius (1953) the finds are also briefly mentioned but again without a more detailed description of the fragments or a more exact indication in which archeological layer they were found.

9 In 1962, Henry Field published a short note on the human fossil remains in the Field Museum of Natural History. Under Point 2, he mentioned that two cranial fragments from a juvenile Neandertal (inventory number 199559) were purchased for the museum in 1930 from the «Dr. F. Krantz» Company in Bonn. The purchase also included typical lithics from Le Moustier. According to accompanying labels, the finds were made at Le Moustier in 1914 by O. Hauser and were sold in Germany before World War I (Field 1962). In the late 1980s, one of us (E.T.) became interested in the Field Museum specimen as a possible juvenile Neandertal, separated the bone fragments from the sediment block (fig. 2) to which they were adhering, reassembled them, but then returned them to the Field Museum as unidentifiable other than appearing to be Pleistocene in age given its fossilization. Subsequently, in 1997, B.M. published a note on the historical origin of the «Le Moustier» remains at the Field Museum of Natural History (Maureille 1997), concluding that this specimen did not belong to either Le Moustier 1 or 2 and that none of the available information indicated that it even came from the Le Moustier sites.

Figure 2 - The hominid skull fragments from Badegoule (0. Hauser excavations), still embedded in the white smooth brecchia. Photograph E. Trinkaus.

Figure 2 - Les deux fragments osseux de Badegoule (fouilles 0 . Hauser) encore pris dans le bloc de sédiment (une brèche claire onctueuse). Photo $\mathrm{E}$. Trinkaus.

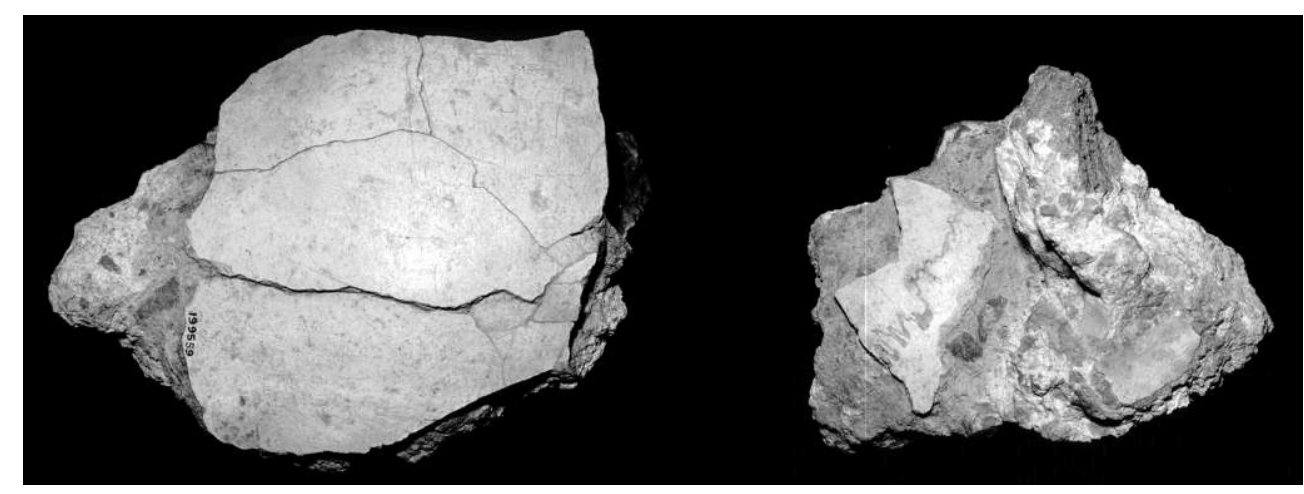

Motivated by this paper and the short article by Hauser (1911b), one of us (W.R.) began to search for further evidence concerning Le Moustier 3. At the same time, contact was made with the «Dr. F. Krantz» Company, in order to establish whether evidence regarding to the pieces in the Field Museum could be found in the archives of the company between 1910 and 1930. To the same end, enquiries were made to D. Wegner of the "Archiv für die Geschichte der Erforschung der Altsteinzeit» (Archive for the History and Study of the Old Stone Age or A.G.E.A.) at Neckarbischofsheim, Germany.

11 Although the enquiries at the Dr. F. Krantz Company gave no results, the search at the A.G.E.A. was more successful. In copies of the «Travel Diaries» of Dr. F. Krantz, «Travel Diary» no. 30 provides descriptions of human remains excavated by Hauser under the entry «Breslau 1.7.1913». This includes mentions of Le Moustier 3, human remains from La Rochette (Hauser 1911a, Orschiedt 2002) and the skull fragment of a child from Badegoule (fig. 3). The entry about the Badegoule find is : «fragment of a child's' skull, Badegoule, Dordogne. Skull fragments embedded in calc-tufa». All finds (La Rochette 1-5, Le Moustier 3 and Badegoule 5) were sent by Hauser to the anatomist H. Klaatsch in 
Breslau for scientific descriptions, where Krantz viewed them as a potential buyer in 1913. Later (probably 1914), Krantz bought Badegoule 5 and Le Moustier 3. As a letter found in the Archives of the Department for Archeology of the Reiss-Engelhorn Museen in Mannheim shows, the remains were offered at the end of November 1915 by Krantz to the artist Prof. Dr. Gabriel Cornelius Ritter von Max who died very shortly after the letter was sent to him. In this letter Krantz wrote that he had sent the same offer list to the Rijksmusem in Leiden, Netherlands and to the Hofmuseum (currently the Naturhistorisches Museum) in Vienna.

Figure 3 - Copy of a double page of the «Travel Diary» no. 30 of Dr. F. Krantz, Bonn. Figure 3 - Copie des pages du journal de voyage $n^{\circ} 30$ du Dr. F. Krantz de Bonn.

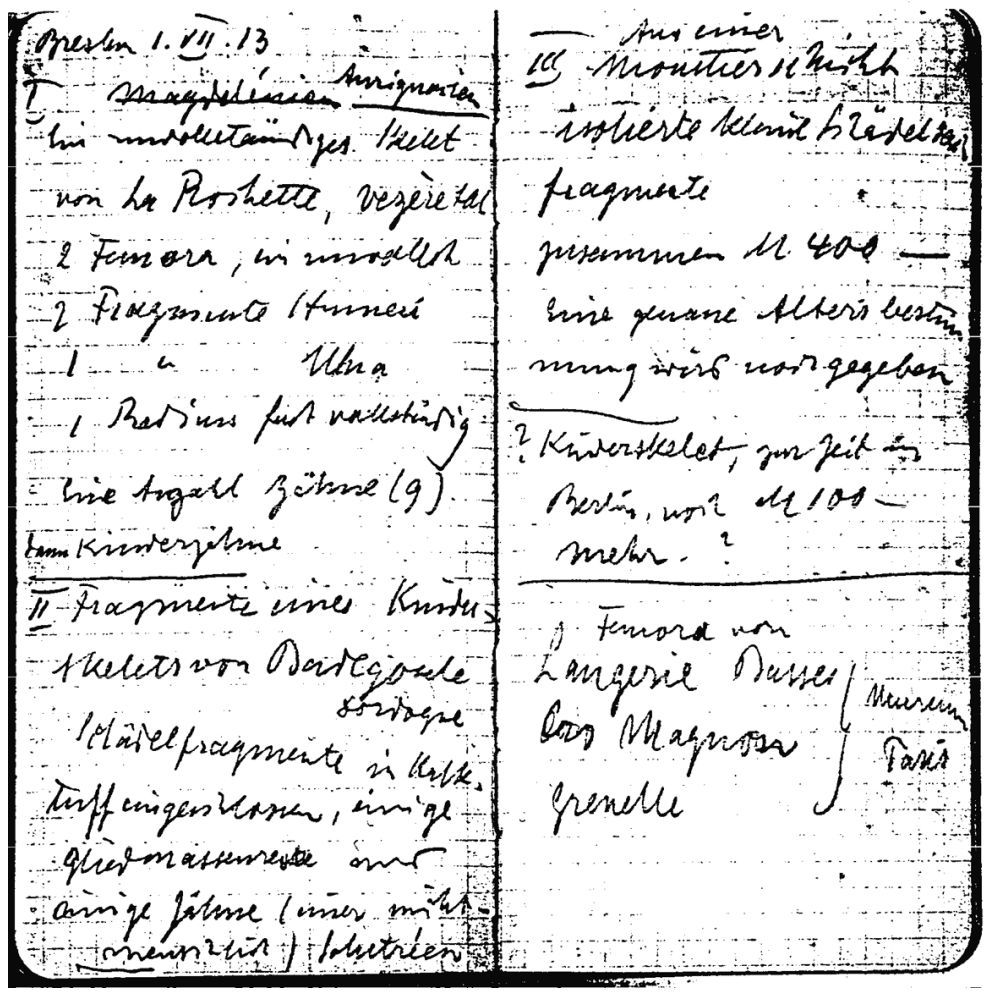

Under the entry «Breslau 1.7.1913, I - III» human remains from La Rochette (I), Badegoule (II) and Le Moustier (III) are mentioned. The entry about the Badegoule 5 find is : "fragments of a child's' skeleton, Badegoule, Dordogne, Skull fragments embedded in calc-tufa».

Concernant son voyage à Breslau le 1.7.1913, on remarque que les restes humains de La Rochette (I), Badegoule (II) et Le Moustier (III) sont mentionnés. Au sujet de Badegoule 5 on peut lire "fragments de crâne d'un enfant, Badegoule, Dordogne, fragments de crânes pris dans une brèche calcaire tendre».

12 We contacted these institutions to ask them if they have, in their archeological collections, materials from Le Moustier Lower rock-shelter and/or Badegoule and, if their answer was positive, if they knew from where these pieces came. We got the answers from these Institutions in April and May 2003. None of them was positive.

In searching for «Le Moustier 3», reference was also found to fragments of a child's skull from Badegoule (Hauser 1911a, 1925). Hauser wrote: «in addition to a nice Solutrean inventory, the year 1910 also brought me a child's skull from Badegoule.....» (Hauser 1911b : 309). Obermaier (1911/12 : 436) also mentioned this find in a short note. The Le Moustier Lower Abri and Badegoule finds are also listed in Vallois and Movius (1953) and in Bouvier (1971 : 149-150). Unfortunately, they did not provide data 
concerning these elements or their source of information. Moreover, Vallois and Movius (1953) noted that these pieces were lost.

Reconsidering these historical data, it is clear that the juvenile skull remains in the Field Museum (Maureille 1997) are very likely to represent the skull fragments of Hauser 1910 child discovery from Badegoule (Rosendahl, in press). The evidence that the skull fragments in Chicago could be those of the child found by Hauser at Badegoule is strengthened by the fact that Krantz wrote that the fragments were embedded in a calc-tufa. Indeed, the similarity between the nature of the sediment removed during the preparation of the Field Museum remains - a calc-tufa very smooth but resistant and the sediment described by Krantz is significant. Moreover, the anatomical evidence, such as the thickness of the cranial vault and the size of the preserved bones indicating that the skull fragments in the Field Museum could come from a 2-3 year old child, fits with the Badegoule discovery (Hauser, ibidem). With respect to the findhorizon, and the published stratigraphies of the Badegoule site (cf. supra), it is likely that the Field Museum specimen represents a human fossil from Badegoulian times.

It is necessary to remember that the hominid remains from the Badegoulian are very rare in the Southwest of Europe (D. Gambier, pers. comm.) One of the best preserved specimens which could be attributed to this period is the isolated calvarium from Rond-du-Barry (Haute-Loire, France) discovered in 1986 (Bayle des Hermens and Heim 1989). But, for the Badegoule 5 specimen, we must consider its chronological attribution with care. Indeed, during the middle of the XXth century, the excavator of Badegoule did not pay close attention to the formation processes of the sedimentoarchaeological levels (for more details about this issue, see Texier 2000). Thus, for a site like Badegoule, this makes very debatable a) the strict correlation of a layer with a precise chronological period of the Paleolithic and b) the degree of integrity of the archaeological sample that it delivered. Only a direct radiocarbon date on the human remains would verify their derivation from the Badegoulian. Note also that the preliminary anatomical investigations of the Badegoule 5 fragments are not able to give a clear answer about their taxonomic status (Maureille 1997).

\section{Comments}

Nonetheless, there are some lacunae in the historical record regarding these fragments. It remains unclear how the incorrect data, or the absence of real site information, came to accompany the finds which were sold by the "Krantz Company» to Henry Field. Moreover, the location of «Le Moustier 3» remains unknown. Does it still exist? The answer to the first question could be the following. In July 1913, Krantz viewed the material in Breslau and negotiated the price. It is probable that the deal was closed with the Krantz Company in 1914, which may have led to the labeling of the finds as «Hauser 1914». The name Hauser referred to the initial excavator and the year 1914 to the year of purchase rather than the year in which the find was made. This could explain Field's writings. Furthermore, there may have been a mix-up of the findlocations (Badegoule/Le Moustier) within the «Krantz Company» at a later date (as it is probable that Krantz also bought «Le Moustier 3» with the Badegoule specimen). Then, in the years up until the sale to Field, in 1927 or 1928, the labels with the find-locations of the human skull fragments from Hauser's excavations could have been interchanged or lost. As a consequence, it is possible that the Le Moustier 3 human remains found by 
Hauser in 1910 are stored somewhere in a collection with an attribution to Badegoule. Moreover, since Field did not buy any human remains labelled as coming from Badegoule, it is highly possible that the Krantz Company had already sold it before this date.

To answer the second question, it seems that the best solution may be to ask, through this paper, the international scientific community for information about any bone remains from the Badegoule site (or also the Le Moustier site) stored in the collections of their institution, specifically a human skull fragment (which could be associated with an isolated tooth). If, somewhere, these remains exist, they have a chance to be, in fact, the Le Moustier 3 hominid pieces. Perhaps, a new Neandertal specimen...

\section{Conclusions}

Our investigations have allowed us to establish - considering the published data about the Badegoule site (Badegoule central and also Badegoule Ouest) - that the hominid child skull fragment discovered by O. Hauser in 1910 (Hauser 1911b) and named Badegoule 5 is almost certainly the one preserved in the collections of the Field Museum of Natural History (inventory number 199559). For the moment, and without new sedimentological investigations at the Badegoule central site, the simplest hypothesis concerning the chrono-cultural position of the Badegoule 5 specimen is to relate it - with care - to the Badegoulian period.

Moreover, it seems that the post-excavation history of the Le Moustier 3 remains has crossed the post-excavation history of the Badegoule 5 specimen and that, somewhere in the world, in an archeological collection, one or two pieces could be inventoried as coming from Badegoule but could be, in fact, from the Le Moustier inferior rockshelter.

\section{Acknowledgments}

Thanks go to Mrs. U. Müller-Krantz, from the company «Dr. F. Krantz» in Bonn and Mr. D. Wegner, «Archive for the History of Old-Stone Age Research» in Neckarbis-chofsheim, Germany for their help with regard to the search for information. Many thanks also to Dr. D. Reese and Dr. S. E. Nash from the Field Museum of Natural History in Chicago, Illinois, USA for their support.

\section{BIBLIOGRAPHY}

BAYLES des HERMES R. and HEIM J.-L. 1989 - Découverte d'un crane humain dans une sépulture secondaire du Magdalénien I de la grotte du Rond-du-Barry, Polignac, Haute-Loire. C. R. Acad. Sc. Paris, 309, p. 1349-1352.

BOUVIER J. 1971 - France, Upper Palaeolithic, Badegoule. In : K.-P. Oakley, B. G. Campbell and T. I. Molleson (Eds.), Catalogue of fossil Hominids, part II : Europe. London : British Mus. (Nat. Hist.), 1971, p. 80-82. 
CHAMPAGNE L. 1905 - L’Homme solutréen de Badegoule. Bull. Soc. Préhist. Fr., 2, p. 223-224.

CHEYNIER A. 1930 - Un outil magdalénien nouveau, en silex, à Badegoule, la raclette. Bull. Soc. Préhist. Fr., 27, p. 483-488.

CHEYNIER A. 1939 - - Le Magdalénien primitif de Badegoule et les niveaux à raclettes. Bull Soc. Préhist. Fr., 36, p. 354-396.

CHEYNIER A. 1948 - Stratigraphie de Badegoule. Bull. Soc. Préhist. Fr., 45, p. 329-330.

CHEYNIER A. 1949 - Badegoule, station Solutréenne et Proto-Magdalénienne. Arch. Inst. Paléont. hum., 23. Paris : Masson, 129 p.

COUCHARD J. 1966 - La stratigraphie du gisement de Badegoule-ouest, commune du Lardin (Dordogne). L'Anthropologie, 70, p. 17-28.

CRETIN C. 2000 (unpublished) - Tradition et variabilité dans le comportement technique. Le cas du Badegoulien et du Magdalénien en Périgord. Thèse de l'Université de Paris I -.

FIELD H. 1962 - Les restes humains fossiles du Musée d'Histoire naturelle de Chicago.

L'Anthropologie, 66, p. 409.

GAMBIER D. and HOUET F. 1993 - France, Upper Palaeolithic. In : R. Orban, J.L. Slachmuylder, P. Semal and D. Roels (Eds.) , Hominid remains, an up-date. Supplément to Anthropologie et Préhistoire $\mathrm{n}^{\circ}$ $6,120 \mathrm{p}$.

HAUSER O. 1911a - Le Périgord préhistorique. Le Bugue : Imp. Réjou, 23 p.

HAUSER O. 1911b - Über die Ergebnisse seiner vorjährigen Ausgrabungen. Zeitschr. f.Ethnologie, 43, p. 308-310.

HAUSER O. 1925 - Urgeschichte. Jena, 206 p.

HAUSER O. 1928 - Der Erde Eiszeit und Sintflut. Weimar, 302 p.

MASSENAT E. 1869 - Objets gravés et sculptés de Laugerie-Basse (Dordogne). Mat. pour l'hist. nat et. prim. de l'homme, 5, p. 348-357.

MAUREILLE B. 1997 - Sur les restes présents au Field Museum of Natural History (Chicago, Illinois, USA) et inventoriés comme provenant du Moustier (Dordogne). Paléo, 9, p.397-399.

OBERMAIER H. 1911/12 - Der Mensch der Vorzeit. Berlin-München-Wien, 436 p.

ORSCHIEDT J. 2002 - Datation d'un vestige humain provenant de La Rochette (Saint-Léon-surVézére, Dordogne) par la méthode du carbon 14 en spectrométrie de masse. Paléo, 14, p. 239-240.

PEYRONY D. 1908 - Nouvelles fouilles à Badegoule: Solutréen supérieur et transition du Solutréen au Magdalénien. Revue préhist., 3, p. 97-116.

ROSENDAHL W. (in press) - Le Moustier 3 : a second Le Moustier Neanderthal discovery by Otto Hauser. In : H. Ullrich (ed.), The Neanderthal Adolescent Le Moustier 1. New Aspects, New Results. Berlin : Berliner Beiträge zur Vor- und Frühgeschichte, pp. 6.

SONNEVILLE-BORDES de D. 1959 - Position stratigraphique et chronologie relative des restes humains du Paléolitique supérieur entre Loire et Pyrénées. Annales de Paléontologie, 45, p. 17-52.

TABORIN Y. and THIEBAULT S. 1994 - Badegoule. In A. Leroi-Gourhan A. (éd.), Dictionnaire de la Préhistoire. Paris : Presses Universitaires de France, p. 103.

TEXIER J.-P. 2000 - A propos des processus de formation de sites préhistoriques. Paléo, 12, p. 379-386. 
VALLOIS H.-V. et MOVIUS Jr. H. L. 1953 - Catalogue des Hommes fossiles. In : C. R. XIXe session Cong. Géol. Intern., commission pour l'Homme fossile, section $V$ : les préhominiens et les hommes fossiles, fasc. V, Alger 1952. Macon : Presses Imp. Protat frères, p. 121-167.

\section{NOTES}

1. Study of Philology, History and Archaeology from 1892 till 1898 at the Universities of Bern and Zurich/Switzerland, Ph.D. in Archaeology («La Micoque - Die Kultur einer neuen Diluvialrasse») in 1916 at the University of Erlangen/Germany.

\section{ABSTRACTS}

In 1910 at the site of Badegoule (Dordogne), O. Hauser discovered cranial remains of a juvenile specimen labelled Badegoule 5. No other information about this specimen or its future was available after 1910. However, unpublished German archives confirm that Badegoule 5 had not been lost or destroyed. In fact, Badegoule 5 is preserved in the collections of the Field Museum of Natural History, Chicago (Illinois) (inventory number is 199559), although it was labelled that it could have derived from Le Moustier (O. Hauser excavations). One of us has had the chance to restore the specimen, and the nature of the sediment which contained these remains confirms our interpretation of the archives. Considering data from excavations of A. Cheynier and J. Couchard of different loci of Badegoule, we infer that the human remains belong to the Badegoulian levels.

Dans le gisement de Badegoule (Dordogne), O. Hauser mis au jour, en 1910, des vestiges crâniens d'un sujet immature (Badegoule 5). Aucune autre information sur ce spécimen n'était disponible tout comme son devenir. Des archives allemandes inédites nous assurent que Badegoule 5 n'a pas été perdu et qu'il fait actuellement partie des collections du Field Museum of Natural History à Chicago (Illinois) où il a été restauré par l'un de nous. Il y est inventorié sous le numéro 199559 et il est mentionné comme provenant du Moustier (fouilles Hauser). La nature du sédiment qui contenait ces vestiges confirme nos investigations sur les archives et nous permet, en fonction des résultats des fouilles de A. Cheynier et J. Couchard (de différents locus de Badegoule), de supposer qu'ils se rapportent aux niveaux badegouliens.

1910 entdeckte O. Hauser in der Fundstelle Badegoule (Dordogne) Schädelfragmente eines Kindes, die unter der Bezeichnung «Badegoule 5» geführt werden. Nähere Informationen zu diesem Fund und seinem Verbleib nach 1910 lagen bisher nicht vor. Unveröffentlichte Dokumente aus Archiven in Deutschland belegen nun, dass die Reste «Badegoule 5» nicht verlorengegangen oder zerstört sind, sondern in den Sammlungen des Field Museum of Natural History in Chicago (Illinois) liegen. Sie werden dort mit der Inventarnummer 199559 und dem Fundstellenbezug «Le Moustier (Ausgrabung O. Hauser)» geführt. Einem der Autoren war es möglich die Schädelreste näher zu untersuchen. Die Charakteristik der Sedimente, in welchen die Schädelfragmente eingebettet waren, bestätigt die Zuweisung des Fundes über die Archivunterlagen nach Badegoule. Die Ergebnisse der von A. Cheynier and J. Couchard an 
verschiedenen Stellen in Badegoule durchgeführten Ausgrabungen zeigen, dass das Sediment mit den Schädelfragmenten wahrscheinlich aus einer Badegoulien-Schicht stammt.

\section{INDEX}

Mots-clés: Badegoule, histoire, Paléolitique supérieur, Solutréen, Badegoulien, vestiges humains Keywords: Badegoule, History, Upper Paleolithic, Solutrean, Badegoulian, human remains

Schlüsselwörter. Badegoule, Forschungsgeschichte, Jungpaläolithikum, Solutréen, Badegoulien, menschliche Skelettreste

\section{AUTHORS}

\section{WILFRIED ROSENDAHL}

Institut für Angewandte Geowissenschaften, Schnittspahnstr. 9, 64287 Darmstadt, Germany. mel: wilfros@geo.tu-darmstadt.de

\section{BRUNO MAUREILLE}

UMR 5809 CNRS, Laboratoire d'Anthropologie, Université Bordeaux 1, avenue des Facultés, 33405 Talence cedex, France. mel: b.maureille@anthropologie.u-bordeaux.fr

\section{ERIK TRINKAUS}

Department of Anthropology, Campus Box 1114, Washington University, St. Louis, MO 63130, USA. mel: trinkaus@artsci.wustl.edu UMR 5809 CNRS, Laboratoire d'Anthropologie, Université Bordeaux 1, avenue des Facultés, 33405 Talence cedex, France. 